\title{
ANALYSIS OF A SEROLOGICAL DETERMINANT OF H-Y ANTIGEN: EVIDENCE FOR CARBOHYDRATE SPECIFICITY USING AN H-Y SPECIFIC MONOCLONAL ANTIBODY
}

\author{
Mark Shapiro* and Ellen H. Goldberg $†$ \\ ${ }^{*}$ Department of Human Genetics, University of Michigan Medical School, Box 015, 1137 \\ E. Catherine Street, Ann Arbor, MI 48109, U.S.A. and †Department of Microbiology, \\ University of New Mexico, School of Medicine, Albuquerque, NM 87131, U.S.A.
}

(Received 23 January 1984; revised version 27 February 1984)

SUMMARY

Using a monoclonal antibody to $\mathrm{H}-\mathrm{Y}$ antigen we characterized the molecular determinant responsible for $\mathrm{H}-\mathrm{Y}$ reactivity. $\mathrm{H}$-Y-positive cells were treated with enzymes which alter carbohydrate structure and then were tested for their ability to absorb monoclonal anti-H-Y antibody. Indications are that the serological determinant recognized by this antibody is a glycoconjugate containing terminal non-reducing and internal galactosyl residues.

\section{INTRODUCTION}

$\mathrm{H}-\mathrm{Y}$ antigen is a minor histocompatibility antigen serologically detectable on the surfaces of cells from the heterogametic sex of a variety of vertebrate species (Wachtel, 1979; Ohno and Matsunaga, 1981) and even on cells from invertebrates (Shalev et al., 1980). In mammals $\mathrm{H}-\mathrm{Y}$ is found almost exclusively in males, and, as such, has been postulated to play a role in primary sex determination (for a review, see Ohno, 1979).

$\mathrm{H}-\mathrm{Y}$ is a weak antigen. Conventional $\mathrm{H}-\mathrm{Y}$ antisera have low titres, are cytotoxic against few cell types and are not readily used in test systems such as ELISA and radioimmunoassay. Different laboratories studying $\mathrm{H}-\mathrm{Y}$ use antisera raised differently and a variety of detection methods, a situation which makes the comparison of independentlyderived experimental results difficult (Goodfellow and Andrews, 1982).

The availability of monoclonal anti-H-Y antibodies may resolve some of these difficulties. We report here the production of a monoclonal anti-H-Y antibody which is male-specific on the basis of its pattern of reactivity both in an indirect cellular radioimmunobinding assay and in a direct cytotoxicity test against isolated mouse

Present address: University of Cincinnati College of Medicine, 231 Bethesda Avenue, Cincinnati. OH 45267, U.S.A.

Correspondence: Ellen H. Goldberg, Department of Microbiology, University of New Mexico, School of Medicine, Albuquerque, NM 87131, U.S.A. 
epidermal cells in the presence of complement. To characterize the molecular determinant responsible for this pattern of reactivity, H-Y-positive cells were treated with enzymes which alter terminal or internal carbohydrate structures and then tested for their ability to absorb the monoclonal anti-H-Y antibody. We provide evidence that the determinant recognized by this antibody is a glycoconjugate containing both terminal non-reducing and internal galactosyl residues.

\section{MATERIALS AND METHODS}

\section{Animals}

C57BL/6 (B6) mice were bred from a stock obtained from the Jackson Laboratories, Bar Harbor, Maine, U.S.A. F344 rats were obtained from the Charles River Breeding Laboratories, Wilmington, Maine, U.S.A.

\section{Cell lines}

The mouse plasmacytoma P3-NSI/1-Ag4-1 was obtained from Dr Noel Warner, University of New Mexico. It is a BALB/c line known not to secrete immunoglobulin.

\section{Preparation of epidermal cells}

Epidermal cells were prepared by the method of Scheid et al. (1972). Mature male B6 mice were killed and the entire piece of skin covering the tail removed. The tail skin was incubated in Puck's Saline F (PSF) containing $1 \%$ trypsin $(2 \times$ crystallized, Gibco) for $50 \mathrm{~min}$ at $37^{\circ} \mathrm{C}$ in order to separate dermis and epidermis. The dermis was discarded and the epidermis placed in Medium 199 (M199, Gibco) containing 10\% heat-inactivated $\left(56^{\circ} \mathrm{C}, 30 \mathrm{~min}\right)$ gammaglobulin free foetal calf serum (FCS). Epidermal cell clumps were teased free of the epidermis by gentle scraping with the tip of a bent, fire-polished pasteur pipette. These clumps were incubated in PSF containing $0.1 \%$ trypsin for $15-20 \mathrm{~min}$ at $37^{\circ} \mathrm{C}$ in order to yield a suspension of single cells. After incubation, a twofold excess of M199 with $10 \%$ FCS was added to the incubation mixture. Free cells were pelleted by centrifugation at $100 \mathrm{~g}$ for $10 \mathrm{~min}$ at $4^{\circ} \mathrm{C}$, then washed three times in M199 containing $10 \%$ FCS. Clumps of cells were removed by centrifugation at $10-20 \mathrm{~g}$ for $5 \mathrm{~min}$. The final suspension of epidermal cells was then adjusted to a concentration of approximately $3 \times 10^{6}$ cells per $\mathrm{ml}$ for use in the direct cytotoxicity test.

\section{Preparation of splenocytes}

Mature mice were killed and their spleens removed. The spleens were placed in Dulbecco's phosphate-buffered saline (PBS), minced, and teased through a screen. The suspension was left for $10 \mathrm{~min}$ to enable large-sized stromal elements to sediment. Splenocytes were pelletted by centrifugation at $400 \mathrm{~g}$ for $10 \mathrm{~min}$ and the pellet washed twice in $0.83 \% \mathrm{NH}_{4} \mathrm{Cl}$, then twice in PBS.

\section{Preparation of antisera}

(1) Rat anti-H-Y antiserum was prepared by the method of Fellous et al. (1978) by immunizing female F344 rats with male (F344) splenocytes. Prior to use in this experiment all antisera were heat-inactivated $\left(56^{\circ} \mathrm{C}, 30 \mathrm{~min}\right)$ and absorbed with equal volumes of female mouse splenocytes, first for $1 \mathrm{~h}$ at $0^{\circ} \mathrm{C}$, then for $1 \mathrm{~h}$ at $37^{\circ} \mathrm{C}$. An antiserum was judged specific for $\mathrm{H}-\mathrm{Y}$ if (1) it had cytotoxic activity against male, but not female B6 epidermal cells and (2) this activity could be absorbed by male, but not female B6 splenocytes. 
(2) $\mathrm{H}-2^{\mathrm{b}}$ antisera, directed against H-2.33 (D-33) and H-2.2 (D2), were obtained from the Transplantation Immunology Branch of the National Institutes of Health, Bethesda, Maryland, U.S.A.

(3) ${ }^{125}$ I-labelled sheep anti-mouse kappa antibody. Sheep anti-mouse kappa serum was kindly provided by Dr Noel Warner, University of New Mexico. The IgG fraction of the antibody was purified by affinity chromatography on a mouse IgG column by Dr K. S. K. Tung, University of New Mexico. The antibody was labelled with $\mathrm{Na}^{125} \mathrm{I}$ (Amersham) at $0.1 \mathrm{mCi} / \mathrm{mg}$ by the chloramine $\mathrm{T}$ method (Greenwood et al., 1963).

\section{Direct cytotoxicity test}

The procedure used to test H-Y antisera is similar to that of Scheid et al. (1972). Equal volumes $(10 \mu \mathrm{l})$ of $\mathrm{H}-\mathrm{Y}$ antiserum, epidermal cells $\left(3 \times 10^{6}\right.$ per $\left.\mathrm{ml}\right)$, and guinea-pig complement (Gibco) diluted $1 / 16$ were incubated at $37^{\circ} \mathrm{C}$ for $50 \mathrm{~min}$. Trypan blue $(10 \mu \mathrm{l}$ of a $0.2 \%$ solution) was added for the final $5 \mathrm{~min}$ of incubation to stain dead epidermal cells. Cell killing was measured by cytotoxic index $(i)$ defined as:

Number of dead cells in test sample - number of cells killed by complement alone

Total number of cells - number of cells killed by complement alone

Anti- $\mathrm{H}-2^{\mathrm{b}}$ antisera were tested for direct cytotoxicity against splenocytes in the following manner. Equal aliquots $(10 \mu \mathrm{l})$ of anti-H $-2^{\mathrm{b}}$ antiserum and B6 splenocytes $\left(8 \times 10^{6}\right.$ per ml) were incubated for $20 \mathrm{~min}$ at room temperature. Ten microlitres of baby rabbit serum (Pel Freez) as a source of complement diluted $1 / 4$ was then added and the suspension incubated at $37^{\circ} \mathrm{C}$ for a further $35 \mathrm{~min}$. Ten microlitres of $0.2 \%$ trypan blue was added for the final 5 min of incubation to stain dead splenocytes. Formalin saline (10 $\mu$ containing $5 \%$ formaldehyde) was added as a fixative and live and dead cells were counted. Cell killing was measured by cytotoxic index $(i)$. All cytotoxicity tests were run on coded samples.

\section{Absorptions}

Aliquots of anti-H-Y antiserum $(25 \mu 1)$ diluted $1 / 4$ were added to known numbers of splenocytes. Suspensions were incubated at $4^{\circ} \mathrm{C}$ for $1 \mathrm{hr}$. Next the absorbing cells were removed from the absorbed antiserum by centrifugation at $400 \mathrm{~g}$ for $10 \mathrm{~min}$ at $4^{\circ} \mathrm{C}$. The resultant antiserum was then tested for residual direct cytotoxicity against isolated male mouse epidermal cells.

\section{Enzyme treatments}

Sensitivity of $\mathrm{H}-\mathrm{Y}$ specific absorption to all treatment is expressed as:

$$
\text { Corrected \% inhibition of absorption }=\frac{A-B}{C-B} \times 100,
$$

where $A=i$ of male cells treated with anti-H-Y antibody previously absorbed with enzyme treated male cells, $B=i$ of male cells treated with anti-H-Y antibody previously absorbed with male cells which were not subject to enzyme treatment, and $C=i$ of male cells treated with anti-H-Y antibody which had not been absorbed.

Galactose oxidase (Sigma) was dissolved in PBS containing $1.0 \mathrm{mg}$ per $\mathrm{ml}$ of bovine serum albumin (BSA, Sigma). Splenocytes were incubated with known amounts of enzyme in PBS ( $\mathrm{pH} \mathrm{7.4)} \mathrm{at} 37^{\circ} \mathrm{C}$ for $1 \mathrm{hr}$. Each incubation mixture contained $4 \times 10^{7}$ splenocytes 
plus enzyme in a volume of $0.5 \mathrm{ml}$. After incubation, treated cells were washed three times in M199 supplemented with $10 \%$ FCS and $1 \mathrm{M}$ galactose prior to absorption.

Purified endo- $\beta$-galactosidase (3.0 units $/ \mathrm{mg}$ protein) from $E$. frendii was the gift of $\mathrm{Dr}$ M. N. Fukuda, Fred Hutchinson Cancer Center, Seattle, Washington, U.S.A. Splenocytes ( $10^{7}$ in the case of the $\mathrm{H}^{-} 2^{\mathrm{b}}$ assays or $4 \times 10^{7}$ in that of the $\mathrm{H}-\mathrm{Y}$ system) were treated in 0.5 $\mathrm{ml}$ incubation volumes containing $0.1 \mathrm{M}$ acetate buffer, $0.07 \mathrm{M} \mathrm{NaCl}$, and 0.0625 units of endo $\beta$-galactosidase at $\mathrm{pH} 5.8$ for $2 \mathrm{hr}$ at $37^{\circ} \mathrm{C}$. Following treatment, cells were washed three times in $\mathrm{M} 199$ containing $10 \% \mathrm{FCS}$ at $4^{\circ} \mathrm{C}$ prior to absorption.

Untreated control samples were handled in a manner identical to treated cells, with the exception that the appropriate enzyme was omitted from the incubation mixture.

\section{${ }^{125}$ I-radioimmunobinding assay}

The radioimmunobinding assay used was a modification of that described by Tsu and Herzenberg (1980). Briefly, single cell suspensions of B6 male or female lymph node lymphocytes were prepared in PBS. After washing three times with PBS by centrifugation at $200 \mathrm{~g}$, they were suspended in PBS at a concentration of $10 \times 10^{6}$ cells $/ \mathrm{ml}$. Fifty microlitres of the appropriate cell suspension were added to each well of a soft plastic microtitre plate (Dynatech Laboratories) that had previously been coated with bovine serum albumin (BSA) made $3 \%$ with PBS. Fifty microlitres of antiserum diluted in PBS $(1 / 2-1 / 128$, at doubling dilutions) were then added to triplicate wells of both male and female cells. After incubating the plate for $30 \mathrm{~min}$ at $4^{\circ} \mathrm{C}$, it was washed three times with BSA made $0.2 \%$ with PBS, by centrifugation at $200 \mathrm{~g}$ for $10 \mathrm{~min}$. The ${ }^{125}$ I-labelled sheep anti-mouse kappa antibody, diluted in 3\% BSA, was then added to each well in $50 \mu \mathrm{l}$ volumes to give 1-2 $10^{5}$ counts per well. After incubating for $30 \mathrm{~min}$ at room temperature, the plate was washed five times and allowed to dry. The amount of ${ }^{125} \mathrm{I}$ bound to the cells in each well was determined and was expressed as a percentage of the male : female binding according to the following formula:

$$
\frac{{ }^{125} \mathrm{I} \mathrm{cpm}(\mathrm{male})-{ }^{125} \mathrm{I} \mathrm{cpm}(\text { female })}{{ }^{125} \mathrm{I} \mathrm{cpm} \mathrm{(male)}} \times 100 \%
$$

\section{RESULTS}

To generate the hybridoma by which the monoclonal anti-H-Y antibody is produced, $10 \mathrm{~B} 6$ female mice were immunized with B6 male splenocytes. After immunization, the B6 females were screened for the production of anti-H-Y antibodies by cytotoxicity against B6 spermatozoa in the presence of complement (Goldberg et al., 1970). The two females most positive for anti-H-Y antibody production were killed, and their splenocytes prepared for fusion with P3-NSI/1-AG4-1 cells, using standard techniques for cell fusion and for maintenance and cloning of hybridomas (Köhler \& Milstein, 1975; Oi \& Herzenberg, 1980). The supernatants of generated clones were screened for anti-H-Y antibody production by the cellular radioimmunobinding assay and, of 100 clones tested, only a single clone produced male-specific antibody.

The positive clone was subcloned by limiting dilution to yield five subclones. Supernatants were collected from the subclones and tested by cellular radioimmunobinding for preferential binding to male lymphocytes. Antibodies from three subclones, 1, 2 and 4 , showed significantly more binding to male than to female mouse lymphocytes, 
TABLE 1. Screening of hybridoma subclone supernatants

(a) ${ }^{125}$ I-radioimmunobinding test against B6 male and female ly mph node lymphocytes

\begin{tabular}{|c|c|c|c|}
\hline \multirow[b]{2}{*}{ Subclone } & \multicolumn{2}{|c|}{${ }^{125} 1(\mathrm{cpm})$ bound to*: } & \multirow{2}{*}{$\begin{array}{c}\text { Per cent } \\
\text { male : female } \\
\text { differencet }\end{array}$} \\
\hline & Male & Fermale & \\
\hline 1 & 1,609 & 986 & $38 \cdot 7$ \\
\hline 2 & 1,035 & 339 & $67 \cdot 2$ \\
\hline 3 & 4,750 & 4,674 & 1.6 \\
\hline 4 & 9,715 & 7,264 & $25 \cdot 2$ \\
\hline 5 & 7,394 & 7,313 & $1 \cdot 1$ \\
\hline
\end{tabular}

(b) Cytotoxicity tests on B6 male and female epidermal cells

\begin{tabular}{ccc}
\hline & \multicolumn{2}{c}{$i \pm$ SEM $\neq$} \\
\cline { 2 - 3 } Subclone & \multicolumn{1}{c}{ Male } & Female \\
\hline 1 & $0.13 \pm 0.01$ & $0.03 \pm 0.03$ \\
2 & $0.18 \pm 0.02$ & $0.04 \pm 0.02$ \\
3 & $0.02 \pm 0.01$ & ND \\
4 & $0.09 \pm 0$ & $0.02 \pm 0.01$ \\
5 & $0.03 \pm 0.02$ & ND \\
\hline
\end{tabular}

\footnotetext{
* Each value represents the average of five experiments. Supernatant was diluted $1 / 16$ at which the greatest percentage of ${ }^{125} \mathrm{I}$ was obtained. The cpm bound to the target cells using ${ }^{125} 1$-labelled sheep antimouse kappa antibody ranged from 100 to 250.

+ See formula given in text.

$\ddagger$ Each value of mean cytotoxic index, $i$, represents the mean of tests performed at three dilutions of supernatant $(1: 2,1: 4$ and $1: 8 \pm$ SEM $)$.
}

whereas those from subclones 3 and 5 did not (Table 1a). The supernatants were also independently tested for direct cytotoxicity against isolated B6 male epidermal cells. In this test the supernatants of subclones 1,2 and 4 had cytotoxic activity against male epidermal cells, whereas supernatants 3 and 5 were not significantly more active than complement alone (Table $1 \mathrm{~b}$ ). In both assays supernatant 2 was more active than 1 or 4 . A representative test using supernatant from subcione 2 is illustrated in Fig. 1.

Supernatants 1, 2 and 4 were tested for cytotoxic activity against male and female B6 epidermal cells. Fig. 2 a shows the pooled data from these cytotoxicity tests presented as a graph of cytotoxic index (i) versus the reciprocal of antibody dilution. The data indicate that the monoclonal antibody is significantly more cytotoxic against male than female epidermal cells.

As another test of male specificity, we determined whether the antibody's cytotoxic activity against male epidermal cells could be preferentially absorbed by male splenocytes. 


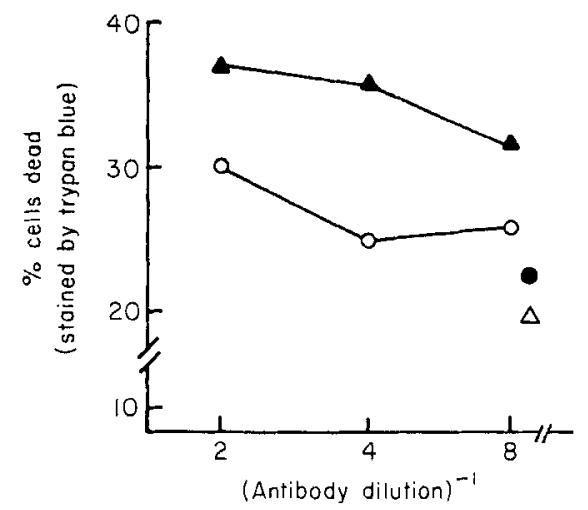

FIG. 1. Detection of H-Y on B6 male epidermal cells by the cytotoxicity test using monoclonal anti-H.Y antibody (subclone 2$)$. ( $\Delta-\mathbf{\Delta}$ ) male target cells; $(\mathrm{O}-\mathrm{O})$ female target cells. $(\Delta$, killing of male, female cells in absence of monocional antibody, i.e. by complement alone.

Supernatants from the three positive subclones were pooled. Aliquots of this antibody solution were diluted and absorbed with known numbers of male and female B6 splenocytes. Absorbed samples were then tested for residual cytotoxic activity against B6 male epidermal cells. Fig. $2 b$ shows a graph of cytotoxic index versus number of absorbing cells. The data indicate that although the cytotoxic activity of the antibody is not appreciably removed by female splenocytes, it can be quantitatively absorbed by male splenocytes.

In an attempt to further characterize the molecular determinant recognized by the monoclonal anti-H-Y antibody, we examined whether the ability of $\mathrm{H}-\mathrm{Y}^{+}$cells to absorb the monoclonal anti-H-Y antibody could be perturbed by treatments which alter carbohydrate structure. We endeavoured to see whether one such treatment, the enzyme galactose oxidase, could inhibit the ability of $\mathrm{H}$-Y-positive cells to absorb the monoclonal antibody. Galactose oxidase oxidizes terminal galactosyl residues at the non-reducing ends of a carbohydrate chain.

Male splenocytes were treated with purified galactose oxidase, then washed in protein and sugar-enriched medium before absorption. Treated splenocytes were used to absorb aliquots of monoclonal anti-H-Y antibody. Fig. 3 shows a graph of corrected per cent inhibition of absorption versus units of enzyme used for treatment. Absorption of the monoclonal antibody is sensitive to galactose oxidase. The maximum treatment employed (10 units) removes $69 \%$ of the absorptive capacity of male mouse splenocytes. This result is consistent with results obtained with conventional anti-H-Y antiserum (Shapiro and Erickson, 1981).

To further extend these observations, we assessed whether H-Y serological activity was affected by the perturbation of internal galactosyl residues. Splenocytes were treated with endo- $\beta$-galactosidase, an enzyme which hydrolyzes glycosidic linkages of galactosyl moieties located proximal to the non-reducing residue of a carbohydrate chain. The cells were then washed in protein supplemented medium. Treated cells were used to absorb either conventional rat anti-H-Y antiserum or monoclonal anti-H-Y antibody. As a control the same treatment was performed on absorbing cells possessing antigens of the $H-2^{b}$ haplotype. H-2 serological determinants are thought to reside in amino acid sequences (Nathenson and Muramatsu, 1971; Pancake and Nathenson, 1973). Whereas H-2 ${ }^{b}$ specific 
(a)

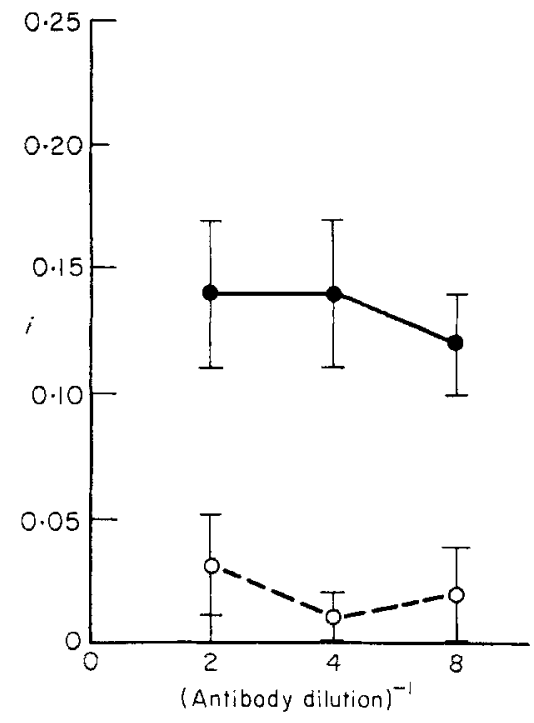

(b)

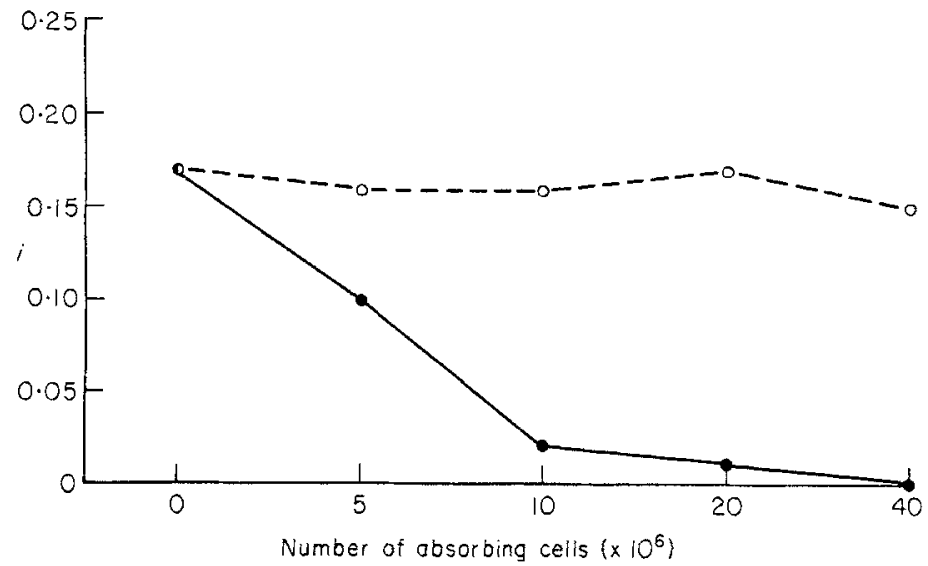

FIG. 2. (a) Cytotoxic specificity of monoclonal anti-H-Y antibody. Cytotoxic index, $i$ (as defined in Materials and Methods), and reciprocal of antibody dilution used, are indicated on the figure. Values shown reprsent the means of triplicate determinations $\pm S E M$. (b) Absorption specificity of monoclonal anti-H-Y antibody. Cytotoxic index, $i$, and numbers of spleen cells used to absorb each aliquot of hybridoma supernatant ( $25 \mu$ lof a $1: 4$ dilution) are indicated on the figure. Values shown represent the means of duplicate determinations. (-) male (epidermal) target cells (Fig. 2a) and male (spleen) absorbing cells (Fig. 2b). (O-- - O) female (epidermal) target cells (Fig. 2a) and female (spleen) absorbing cells (Fig. 2b).

absorption is completely insensitive to endo- $\beta$-galactosidase, $\mathrm{H}-\mathrm{Y}$ serological activity is inhibited by this treatment (Table 2). Absorption of conventional rat anti-H-Y antiserum was reduced by $67 \%$ and monoclonal anti-H-Y antibody by $69 \%$.

Considered together, the data from both enzyme treatments suggest that serological recognition of $\mathrm{H}-\mathrm{Y}$ antigen is dependent upon the integrity of a carbohydrate sequence containing internal as well as terminal non-reducing galactosyl residues. 


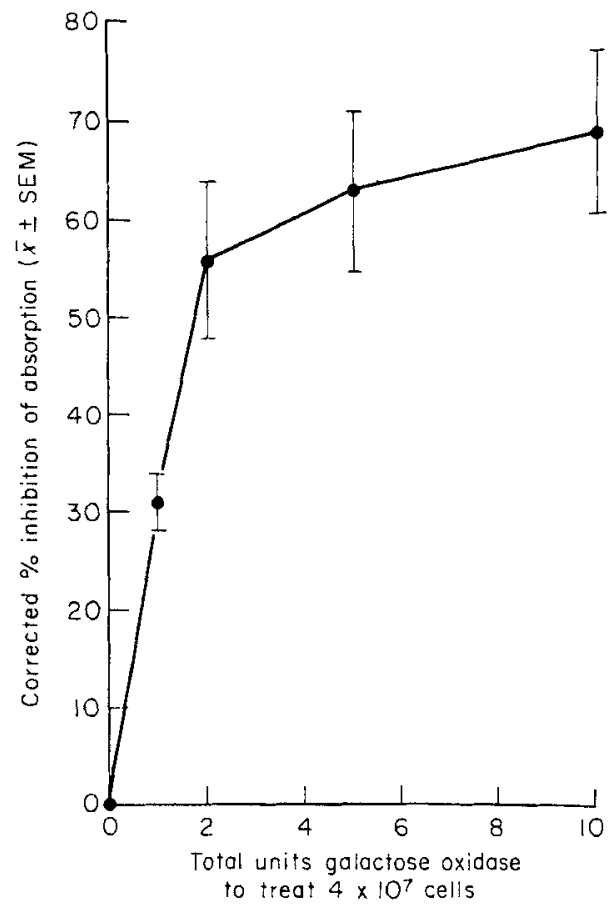

FIG. 3. Monoclonal anti-H-Y antibody: sensitivity of $\mathrm{H}$-Y-specific absorption to galactose oxidase treatment. Corrected percent inhibition of absorption (as defined in Materials and Methods) and number of units of enzyme used for treatment are indicated on the figure. Values shown represent the means of triplicate determinations \pm SEM. (Representative test.) Also, see legend to Table 2.

TABLE 2. H-Y-specific absorption: sensitivity to endo- $\beta$ galactosidase treatment*

\begin{tabular}{lcc}
\hline \multicolumn{1}{c}{ Antibody } & $\begin{array}{c}\text { Antibody } \\
\text { dilution } \\
\text { used }\end{array}$ & $\begin{array}{c}\text { Percent } \\
\text { inhibition of } \\
\text { absorption } \\
\text { (mean } \pm \text { SEM) }\end{array}$ \\
\hline Rat anti-H-Y & $1: 4$ & $67 \pm 4$ \\
Monoclonal anti-H-Y & $1: 4$ & $69 \pm 4 \dagger$ \\
Anti-H-2 & $1: 100$ & $4 \pm 1$ \\
\hline
\end{tabular}

* Endo- $\beta$-galactosidase treatments were as described in Materials and Methods. Values shown represent the means of quadruplicate (H-Y-specific absorption) or duplicate (H-2 ${ }^{\mathrm{b}}$-specific absorption) determinations $\pm \mathrm{SEM}$.

$\dagger$ The percentage of dead cells obtained with monoclonal anti-H-Y supernatant previously absorbed with enzyme-treated male cells was 26-37\% higher than that obtained when the supernatant was absorbed with untreated male cells. 


\section{DISCUSSION}

Our monoclonal anti-H-Y antibody is characterized as H-Y-specific on the basis of its pattern of reactivity in an indirect cellular radioimmunobinding assay and a direct cytotoxicity test in the presence of complement. In the latter test, serological activity is also shown to be absorbed by male, but not female mouse splenocytes, providing additional evidence of $\mathrm{H}-\mathrm{Y}$ specificity.

In an attempt to further characterize the molecular determinant recognized by this antibody, $\mathrm{H}$-Y-positive cells were treated with galactose oxidase and then tested for their ability to absorb monoclonal anti-H-Y antibody. In this experiment the absorptive capacity of H-Y-positive splenocytes is reduced by galactose oxidase treatment, a result consistent with data presented elsewhere using conventional rat anti-H-Y antiserum (Shapiro and Erickson, 1981). This supports the notion that H-Y-specific absorption is dependent upon a carbohydrate containing a terminal non-reducing galactosyl residue.

It should be noted that in the earlier experiment galactose oxidase diminished the ability of treated cells to absorb conventional rat anti-H.Y antiserum by, at most, $38 \%$, a value considerably less than the $69 \%$ inhibition obtained using the monoclonal antibody. This difference may reflect intrinsic variation in the experiment, since variation in the percent inhibition measured is a composite of variation in galactose oxidase treatment, absorption of the antibody, and the direct cytotoxicity test. However, we consider this explanation unlikely because the values of percent inhibition of absorption varied by no more than $15 \%$ in this experiment. A more plausible explanation is that conventional anti-H-Y sera contain a repertoire of distinct antibody molecules of which this monoclonal antibody represents only one. It is likely that the production of further monoclonal anti-H-Y antibodies will generate reagents capable of reacting with carbohydrates of different apparent specificity, or amino acid determinants. Determinants of carbohydrate and amino acid character are reported to be recognized by a panel of monoclonal antibodies to murine Ia antigens (Higgins et al., 1980).

To further examine the dependence of H-Y serological activity on carbohydrate structure, $\mathrm{H}-\mathrm{Y}$ positive splenocytes were treated with endo- $\beta$-galactosidase, which hydrolyzes internal $\beta$-galactosidic linkages. This enzyme inhibits the ability of treated splenocytes to absorb both conventional rat antiserum and the monoclonal anti-H-Y antibody. This suggests that $\mathrm{H}-\mathrm{Y}$ serological determinants are either dependent upon or attached via internal galactosyl residues within a polysaccharide structure. Unlike the case of galactose oxidase treatment, absorption of both reagents appears to be inhibited at the same level in endo- $\beta$-galactosidase treated cells. Further, this level of inhibition is comparable to that observed when galactose oxidase treated cells are used to absorb monoclonal anti-H-Y antibody. If indeed both reagents are recognizing a carbohydrate sequence, the monocional antibody may be one of a number of distinct immunoglobulin molecules each of which recognizes a carbohydrate structure bearing multiple determinants. If these determinants were all physically linked to an internal galactosyl moiety, yet only a subset of them contained a terminal non-reducing galactose, one could account for the observation that galactose oxidase interferes with absorption of the monoclonal anti-H-Y antibody more than that of the conventional, presumably multispecific, reagent.

\section{ACKNOWLEDGMENTS}

We thank Dr M. N. Fukuda for her gift of purified endo- $\beta$-galactosidase, Dr Robert P. 
Erickson for laboratory facilities and his critical reading of the manuscript, and Mrs Rena Jones and Ms Gloria Boyer for excellent secretarial assistance. This work was supported by grant HD 11738 (to Robert P. Erickson), AI/HD11560 (to Ellen H. Goldberg), and Predoctoral Training Grant GM 7544 from the N.I.H. Ellen H. Goldberg is a recipient of N.I.H. Research Career Development Award \#A1 00353. Portions of this report are included as part of a dissertation submitted by Mark Shapiro in partial fulfillment of the Ph.D. degree at the Horace H. Rackham School of Graduate Studies of the University of Michigan.

\section{REFERENCES}

Fellous, M., Günther, E., Kemler, R., Wiels, J., Berger, R., Guenet, J.L., Jakob, H. \& Jacob, F. (1978) Association of the H.Y male antigen with $\beta_{2}$-microglobulin on human lymphoid and differentiated mouse teratocarcinoma cell lines. Journal of Experimental Medicine, 148, 58.

GoldberG, E.H., Aoki. T., Boyse, E.A. \& BenNeTt, D. (1970) Detection of H-2 antigens on mouse spermatozoa by the cytotoxicity test. Nature, 228, 570 .

GOoDfELLOW, P.N. \& ANDREWS, P.W. (1982) Sexual differentiation and H-Y antigen. Nature, 295. 11.

Greenwood, F.C., HUNTER, W.M. \& GLover, J.S. (1963) The preparation of ${ }^{131}$ I-labeled human growth hormone of high specific radioactivity. Biochemical Journal. 89, 114.

Higgins, T.J., Parish, C.R., Hogarth, P.M., McKenzie, I.F.C. \& Hämmerling, G.J. (1980) Demonstration of carbohydrate- and protein-determined Ia antigens by monoclonal antibodies. Immunogenetics. $11,467$.

KöHLeR, G. \& Mitstein, C. (1975) Continuous cultures of fused cells secreting antibody of predefined specificity. Nature, 256, 495 .

Nathenson, S.G. \& Muramatsu, T. (1971) Properties of the carbohydrate portion of mouse $H-2$ alloantigen glycoproteins. In: Glycoproteins of Blood Cells and Plasma (Ed by G. A. Jamieson \& J. Greenwalt), pp. 245-262. Lippincott, Philadelphia.

OhNo, S. (1979) Major Sex Determining Genes. Springer, Berlin.

OhNo, S. \& MatsunaGa, $T$. (1981) The role of H-Y plasma membrane antigen in the evolution of the chromosomal sex determining mechanism. In: Levels of Genetic Control (Ed by S. Subtelny \& U.K. Abbott), p. 235. A.R. Liss, New York.

OI. V.T. \& HeRzENBERg, L.A. (1980) Immunoglobulin-producing hybrid cell lines. In: Selected Methods in Cellular Immunologv (Ed by B. Mishell \& S. Shiigi), p. 351. Freeman, San Francisco.

PANCAKE, S.J. \& NATHENSON, S.G. (1973) Selective loss of H-2 antigenic reactivity after chemical modification. Joumal of Immunology 111, 1086.

SCheid, M., Boyse, E.A.. CARswell, E.A. \& OLd, L.J. (1972) Serologically demonstrable alloantigens of mouse epidermal cells. Journal of Experimental Medicine, 135, 938.

Shalev, A., Goldenberg, P.Z. \& Huebner, E. (1980) Evidence for an H-Y cross-reactive antigen in invertebrates. Differentiation, 16, 77.

ShapIRo, M. \& ERICKSON, R.P. (1981) Evidence that the serological determinant of H-Y antigen is carbohydrate. Nature, 290, 503.

Tsu, T.T. \& HERzENBERG, L.A. (1980) Solid phase radioimmunoassay. In: Selected Methods in Cellular Immunology (Ed by B. Mishell \& S. Shiigi), p. 373. Freeman, San Francisco.

WACHTEL, S.S. (1979) Primary sex determination: H-Y antigen and the development of the mammalian testis. Arthritis and Rheumatism, 22, 1200. 